\title{
The employment of FTIR spectroscopy and chemometrics for authentication of essential oil of Curcuma mangga from candle nut oil
}

\author{
${ }^{1}$ Khudzaifi, M., ${ }^{2}$ Retno, S.S. and ${ }^{2,3 *}$ Rohman, A. \\ ${ }^{1}$ Faculty of Pharmacy, Gadjah Mada University, Yogyakarta, Indonesia \\ ${ }^{2}$ Department of Pharmaceutical Chemistry, Faculty of Pharmacy, Universitas Gadjah Mada, Yogyakarta, \\ Indonesia \\ ${ }^{3}$ Institute of Halal Industry and Systems, Universitas Gadjah Mada, Yogyakarta 55281 Indonesia
}

\section{Article history:}

Received: 14 September 2019

Received in revised form: 22

October 2019

Accepted: 26 October 2019

Available Online: 9

December 2019

Keywords:

Essential oil,

Curcuma mangga Val.,

FTIR spectroscopy,

Partial least square,

Discriminant analysis

DOI:

https://doi.org/10.26656/fr.2017.4(2).313

\begin{abstract}
The adulteration of high price oil such as essential oil of Curcuma mangga Val. (EOCM) with lower price oil is common to get economical profit. This study was to investigate the authentication of EOCM toward candlenut oil (CNO) using FTIR spectroscopy combined with multivariate calibration and discriminant analysis. The selection of $\mathrm{CNO}$ as adulterant oil model was due to its close similarity to EOCM in terms of FTIR spectra. Besides, EOCM has similar color with $\mathrm{CNO}$, therefore, $\mathrm{CNO}$ is potential adulterant toward EOCM. Two multivariate calibrations of partial least square regression (PLSR) and principle component regression (PCR) along with FTIR spectra (normal versus derivatization) were optimized to get prediction models for quantification. The results showed that the combination of PLSR and normal FTIR spectra at optimized wavenumbers of 1614-1068 $\mathrm{cm}^{-1}$ was capable of predicting the levels of EOCM adulterated with CNO. Discriminant analysis was also success to differentiate the classification of EOCM and EOCM adulterated with CNO with accuracy levels of $100 \%$. Using FTIR spectroscopy for oil authentication is rapid, simple without any chemicals, solvents, and sample preparation so that this technique is considered as a green analytical method.
\end{abstract}

\section{Introduction}

Curcuma mangga Valeton and Van Zijp., belonging to Zingiberaceae family, known as Temu mangga (Indonesia) possessing mango-like aroma, is used for flavouring steamed and baked fish due to its aromatic properties (Liu and Nair, 2019). Its rhizome contains curcuminoids and diterpenes which have several biological activities including anti-inflammatory (Kaewkroek et al., 2010) and antioxidant effects through antiradical and reducing power evaluations (Indis and Kurniawan, 2016; Tamta et al., 2016). This plant is reported to have wound healing effects after tissue damage (Sriroda and Tewtrakul, 2019). Besides, labdane diterpenes are also reported to inhibit lipid peroxidation, cyclooxygenase enzymes, and human tumour cell proliferation (Liu and Nair, 2011) and to treat gastric ulcer, chest pain, fever, and skin disease (Abas et al., 2005).

The mango-like aroma in C. mangga originates from volatile components present in essential oils. Some chemical components have been identified from the essential oil of C. mangga (EOCM). Wong et al. (1999) reported that EOCM contained 44 components in which monoterpene hydrocarbons were dominant, followed by $\beta$-myrcene, (E)- $\beta$-ocimene, $\beta$-pinene and $\alpha$-pinene. Padalia et al. (2013) reported that EOCM was dominated by monoterpenoids comprising of $\beta$-myrcene, $\beta$-pinene, (E)- $\beta$-ocimene. Some minor constituents like camphene, 1,8-cineole, limonene/ $\beta$-phellandrene, curzerenone, caryophyllene oxide, borneol, as well as camphor, isoborneol, camphene, borneol and camphene hydrate have been reported (Tamta et al., 2016). EOCM has been reported to show the strong antibacterial activities against Staphylococcus aureus, Bacillus cereus, Pseudomonas aeruginosa, antifungal activity against Candida albicans and Cryptococcus neoformans (Kamazeri et al., 2012) and antioxidant activities (Jena et al., 2017).

Due to its activities, EOCM has a higher price value than other vegetable oils such as palm and corn oils, and it may be adulterated with other lower price oils. Because of such reasons, physicochemical analytical techniques which are reliable for adulteration analysis of 
EOCM are highly needed. Some methods have been proposed, developed and used for authentication of high price oils such as molecular spectroscopy (Lankmayr et al., 2004), nuclear magnetic resonance spectroscopy (Dais and Hatzakis, 2013), differential scanning calorimetry (Van Wetten et al., 2015), chromatographic techniques, namely high performance liquid chromatography (Flores et al., 2006; Bajoub et al., 2017), gas chromatography using flame ionization detector (Jafari et al., 2009), gas chromatography in combination with atmospheric pressure chemical ionization-time of flight (García-Villalba et al., 2011), and real-time polymerase chain reaction (Giménez et al., 2010; Alonso-Rebollo et al., 2017). These methods were time-consuming, needed sophisticated instruments and involved complex sample preparation, indeed, these methods were not preferred to be applied in routine monitoring systems. This condition has challenged some analytical chemists to develop a rapid and reliable technique, especially based on spectroscopic methods such as FTIR spectroscopy.

Fourier transform infrared (FTIR) in combination with chemometrics of classification such as discriminant analysis and multivariate calibration of partial least square (PLS) and principle component regression has been used for authentication analysis of pumpkin seed oil (Irnawati et al., 2019), olive oil (Nurwahidah et al., 2019), sesame oil (Nurrulhidayah et al., 2014), beef meatball (Rahayu et al., 2018), and fish patin oil (Putri et al., 2019). However, using literature review, there are no reports regarding the authentication of EOCM from other oils using FTIR spectroscopy. Therefore, in this study, FTIR spectroscopy combined with chemometrics of multivariate calibrations and classification of discriminant analysis was performed for authentication of EOCM from candlenut oil adulteration.

\section{Materials and methods}

\subsection{Materials}

The rhizomes of Curcuma mangga Val. were collected from Terong Village, Dlingo, Bantul, Yogyakarta on September 2018. The rhizomes were cleaned and thinly chopped into small pieces using a cutter. The chopped rhizomes were air-dried in a room for 3 days. The essential oils of rhizomes of C. mangga Val. (EOCM) oil was isolated using water steamed distillation according to Astuti et al. (2014). The distillation process was taken for 6 hours, and the obtained EOCM was collected in a small clean bottle and stored in a freezer until it was used for further authentication analysis. For the comparations, garlic oil, extra virgin olive oil, corn oil, castor oil, citrus oil, caraway oil, soybean oil, coconut oil, candlenut oil, cananga oil, sunflower oil, rose oil, palm oil, sesame oil and olive oil were purchased from several local markets and supermarkets around Yogyakarta, Indonesia.

\subsection{Principal component analysis (PCA) of oils}

The FTIR spectra of essential oils extracted from $C$. mangga Val. (EOCM) and the comparing oils were subjected to principal component analysis (PCA). Oil having similar score plots of first principle component (PC1) and second principle component (PC2) based on the absorbance values at whole mid infrared regions $\left(4000-650 \mathrm{~cm}^{-1}\right)$ to that of EOCM was used as the oil adulterant (Che Man et al., 2011).

\subsection{Preparation of calibration and validation samples}

In the quantification analysis, a series of calibration and validation or prediction samples with known concentrations of $\mathrm{CNO}$ and EOCM were prepared as in Irnawati et al. (2020). For preparing the calibration samples, twenty-one samples consisting of EOCM in the binary mixtures with $\mathrm{CNO}$ at concentration ranges of 0 $100.0 \% \mathrm{v} / \mathrm{v}$ were made. For preparing the validation samples, a series of different samples were made in the concentration ranges covered by the calibration samples. All samples were analyzed using FTIR spectrophotometer.

\subsection{Discriminant analysis (DA)}

In the classification of genuine EOCM and that adulterated with $\mathrm{CNO}$, a chemometric of supervised pattern recognition of discriminant analysis (DA) was used. The genuine EOCM and that adulterated with CNO were prepared in the concentration range of $0.5-50.0 \%$ $(\mathrm{v} / \mathrm{v})$. Pure EOCM was assigned as authentic, meanwhile, EOCM and that adulterated with $\mathrm{CNO}$ was assigned with "adulterated". Both classes were classified and discriminated using DA on the basis of their FTIR spectra.

\subsection{FTIR spectra acquisition}

All FTIR spectra were acquired from FTIR spectrophotometer (Thermo Scientific Nicolet iS10, Madison, WI), controlled with the operating software of Omnic $\AA$. The measurements were performed in mid infrared region of 4000-650 $\mathrm{cm}^{-1}$ with the resolution was $8 \mathrm{~cm}^{-1}$ and the number of scanning of 32 using horizontal attenuated total reflectance (HATR) composed of $\mathrm{ZnSe}$ crystal. All FTIR spectra were corrected against the FTIR spectrum of air as the background. After every scan, a new reference air background spectrum was taken. To facilitate the quantitative analysis, these spectra were recorded as absorbance values at each data point in triplicate. 


\subsection{Chemometrics analysis}

Chemometrics of classification using discriminant analysis and multivariate calibrations of partial least square regression was performed using TQ Analyst software version 9 (Thermo Fisher Scientific, Inc.). Principal component analysis of EOCM and other oils was carried out using software Minitab version 17 (Minitab Inc., USA).

\section{Results and discussion}

In this study, the essential oil of Curcuma mangga Val. (EOCM) was authenticated from other oils using FTIR spectroscopy in combination with several chemometrics techniques of unsupervised pattern recognition namely principal component analysis (PCA), supervised pattern recognition of discriminant analysis, and multivariate calibration of partial least square regression (PLSR). PCA was used to determine which oils having the closest similarity with EOCM based on the FTIR spectra. The output of PCA is known of score plot of first principle component analysis (PC1) and second principle component ( $\mathrm{PC} 2)$ in which samples having similar $\mathrm{PC} 1$ and $\mathrm{PC} 2$ are similar in nature depending the variables used (Rohman and Putri, 2019). Figure 1 revealed that the score plots of $\mathrm{PC} 1$ and $\mathrm{PC} 2$, EOCM has the closest similarity to that of candlenut oil (CNO), therefore $\mathrm{CNO}$ was selected as oil adulterant to EOCM.

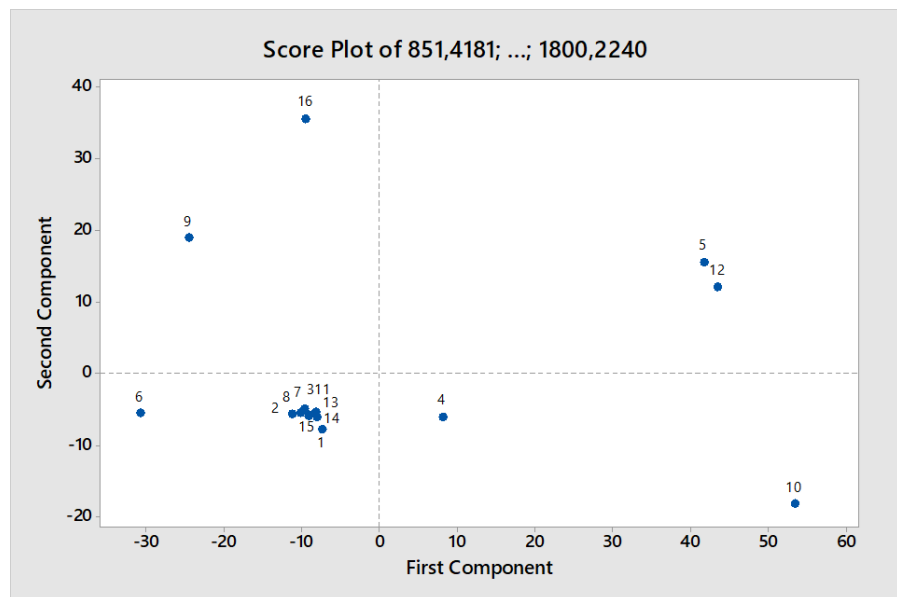

Figure 1. The PCA score plot of essential oil C. mangga Val. (16) and other oils. 1 = garlic oil; $2=$ extra virgin olive oil; 3 $=$ corn oil; $4=$ castor oil; $5=$ citrus oil; $6=$ caraway oil; $7=$ soybean oil; $8=$ coconut oil; $9=$ candlenut oil; $10=$ cananga oil; $11=$ sunflower oil; $12=$ rose oil; $13=$ palm oil; $14=$ sesame oil; $15=$ olive oil.

Figure 2 exhibits FTIR spectra of essential oil of $C$. mangga Val. (EOCM) and candlenut oil (CNO) scanned at wavenumbers of $4000-650 \mathrm{~cm}^{-1}$ using horizontal attenuated total reflectance (HATR) as a sampling technique. Both FTIR spectra exhibited some differences due to the main components in both oils are different.
EOCM was mainly composed of monoterpenes (Abbas et al., 2019), while CNO was typically composed of triglycerides (Jimenez-Carvelo et al., 2017).

Each peak in certain frequency (wavenumbers) in FTIR spectra corresponded to functional groups which absorb IR radiation. The peak at 3007 is due to the stretching vibration of cis $\mathrm{C}=\mathrm{CH}$, while the peak at 2953 $\mathrm{cm}^{-1}$ and 2920 originate from the asymmetric stretching vibrations of methyl $\left(-\mathrm{CH}_{3}\right)$ and methylene $\left(-\mathrm{CH}_{2}\right)$ groups. The peaks at $2873 \mathrm{~cm}^{-1}$ come from symmetric stretching vibration of methyl $\left(-\mathrm{CH}_{3}\right)$ group. The carbonyl $(\mathrm{C}=\mathrm{O})$ stretching vibration was observed at $1744 \mathrm{~cm}^{-1}$, while the peak at 1640 is from the stretching vibration of $\mathrm{C}=\mathrm{C}$. The bending vibrations of methylene and methyl were observed at wavenumbers of 1446 and $1378 \mathrm{~cm}^{-1}$ respectively. The peak at $1105 \mathrm{~cm}^{-1}$ comes from C-O vibrations. While, peaks at 988 and 892 originate from the bending out of plane vibrations of $\mathrm{HC}=\mathrm{CH}-$ (trans) and $-\mathrm{HC}=\mathrm{CH}-($ cis $)$, respectively (Arslan et al., 2019).

FTIR spectroscopy is considered as fingerprint analytical method, therefore, this technique is ideal for differentiation and quantification of analytes of interest in the samples. Quantitative analysis of EOCM in binary mixtures with $\mathrm{CNO}$ was performed using optimized FTIR spectra regions facilitated with multivariate calibrations of partial least square (PLS) and principle component regression (PCR). Both PCR and PLSR are inverse regression in which concentration of analytes $(y$ axis) was modelled with predictors of principle components, a linear combination of absorbance values of FTIR spectra of evaluated samples (x-axis) (Manaf et al., 2007). PCR performs multiple inverse calibration of predictor variables against the scores or principle components (PCs) rather than original variables. PCR uses regression to converts PCs into concentration. PCs are obtained during principal component analysis (PCA). In addition, PLS finds the directions of greatest variability by comparing both spectral and target property information with the new axes, called PLS components. The optimum number of factors used to build PCR and PLS models are depending on the analytical target and properties of samples (Rohman and Putri, 2019).

FTIR spectra along with multivariate calibrations of PLS and PCR were optimized to get the prediction models between actual values of EOCM and FTIR predicted values. The parameters used to decide whether FTIR spectral regions and multivariate calibration chosen are based on the high coefficient of determination $\left(\mathrm{R}^{2}\right)$ and low lowest root mean square of calibration 


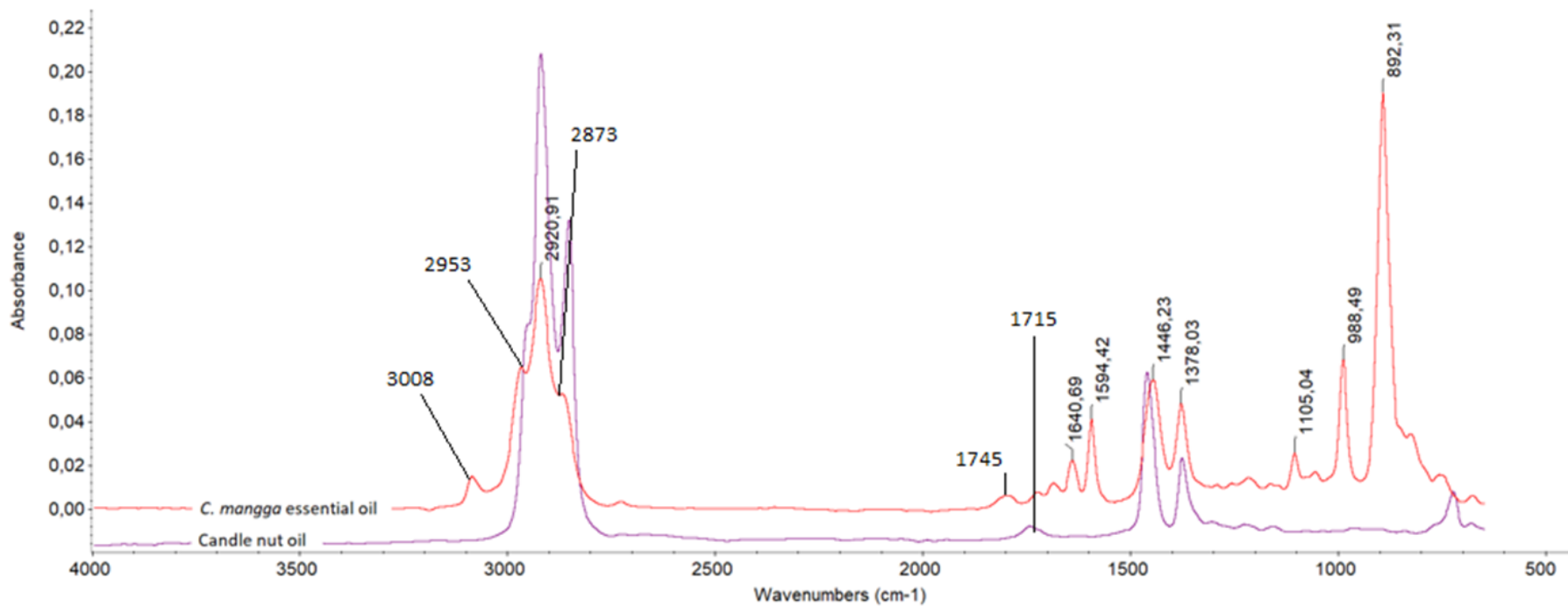

Figure 2. FTIR spectra of $C$. mangga Val. Essential Oil (CMEO) and Candle Nut Oil (CNO) scanned at mid infrared region (4000-650 cm-1) using attenuated total reflectance mode.

Table 1. The results of FTIR spectroscopy using different wavenumbers and spectral treatments coupled with multivariate calibration intended for prediction of $C$. mangga Val. Essential Oil (CMEO) levels adulterated with Candlenut Oil (CNO).

\begin{tabular}{|c|c|c|c|c|c|c|}
\hline \multirow{2}{*}{ Multivariate calibrations } & \multirow{2}{*}{ Wavenumber $\left(\mathrm{cm}^{-1}\right)$} & \multirow{2}{*}{ Spectra } & \multicolumn{2}{|c|}{ Calibration } & \multicolumn{2}{|c|}{ Validation } \\
\hline & & & $\overline{\mathrm{R}^{2}}$ & RMSEC & $\overline{\mathrm{R}^{2}}$ & RMSEP \\
\hline \multirow{18}{*}{ PCR } & \multirow{3}{*}{$3100-663$} & normal & 0.9999 & 0.508 & 0.1 & 0.419 \\
\hline & & derivative 1 & 0.9999 & 0.444 & 0.9999 & 0.494 \\
\hline & & derivative 2 & 0.9999 & 0.413 & 0.9999 & 0.503 \\
\hline & \multirow{3}{*}{$1850-663$} & normal & 0.9999 & 0.489 & 0.1 & 0.419 \\
\hline & & derivative 1 & 0.9999 & 0.418 & 0.9999 & 0.499 \\
\hline & & derivative 2 & 0.9999 & 0.39 & 0.9999 & 0.53 \\
\hline & \multirow{3}{*}{$3100-2700$} & normal & 0.9998 & 0.55 & 0.1 & 0.374 \\
\hline & & derivative 1 & 0.9998 & 0.601 & 0.9999 & 0.442 \\
\hline & & derivative 2 & 0.9999 & 0.42 & 0.9999 & 0.533 \\
\hline & \multirow{3}{*}{$1614-1068$} & normal & 0.9999 & 0.477 & 0.9999 & 0.463 \\
\hline & & derivative 1 & 0.9999 & 0.484 & 0.9999 & 0.563 \\
\hline & & derivative 2 & 0.9999 & 0.456 & 0.9999 & 0.484 \\
\hline & \multirow{3}{*}{$3100-2700$ and $1850-663$} & normal & 0.9998 & 0.543 & 0.9999 & 0.423 \\
\hline & & derivative 1 & 0.9998 & 0.532 & 0.9999 & 0.447 \\
\hline & & derivative 2 & 0.9999 & 0.442 & 0.9999 & 0.551 \\
\hline & \multirow{3}{*}{$3100-2700$ and $1614-1068$} & normal & 0.9998 & 0.563 & 0.1 & 0.408 \\
\hline & & derivative 1 & 0.9998 & 0.577 & 0.9999 & 0.435 \\
\hline & & derivative 2 & 0.9999 & 0.509 & 0.9999 & 0.515 \\
\hline \multirow{18}{*}{ PLSR } & \multirow{3}{*}{$3100-663$} & normal & 0.9999 & 0.544 & 0.1 & 0.391 \\
\hline & & derivative 1 & 0.9999 & 0.476 & 0.9999 & 0.471 \\
\hline & & derivative 2 & 0.9998 & 0.534 & 0.9999 & 0.465 \\
\hline & \multirow{3}{*}{$1850-663$} & normal & 0.9998 & 0.531 & 1 & 0.341 \\
\hline & & derivative 1 & 0.9999 & 0.483 & 0.9999 & 0.495 \\
\hline & & derivative 2 & 0.9998 & 0.522 & 0.9999 & 0.549 \\
\hline & \multirow{3}{*}{$3100-2700$} & normal & 0.9998 & 0.567 & 0.9999 & 0.452 \\
\hline & & derivative 1 & 0.9999 & 0.382 & 0.9999 & 0.533 \\
\hline & & derivative 2 & 0.9999 & 0.306 & 0.9998 & 0.724 \\
\hline & \multirow{3}{*}{$1614-1068$} & normal & 0.9999 & 0.485 & 0.9999 & 0.451 \\
\hline & & derivative 1 & 0.9999 & 0.496 & 0.9999 & 0.499 \\
\hline & & derivative 2 & 0.9999 & 0.509 & 0.9999 & 0.502 \\
\hline & \multirow{3}{*}{$3100-2700$ and $1850-663$} & normal & 0.9998 & 0.543 & 1 & 0.401 \\
\hline & & derivative 1 & 0.9998 & 0.53 & 0.9999 & 0.448 \\
\hline & & derivative 2 & 0.9998 & 0.534 & 0.9999 & 0.458 \\
\hline & \multirow{3}{*}{$3100-2700$ and $1614-1068$} & normal & 0.9998 & 0.575 & 1 & 0.346 \\
\hline & & derivative 1 & 1 & 0.263 & 0.9998 & 0.605 \\
\hline & & derivative 2 & 0.9999 & 0.437 & 0.9999 & 0.551 \\
\hline
\end{tabular}

The selected variables were marked with bold. 


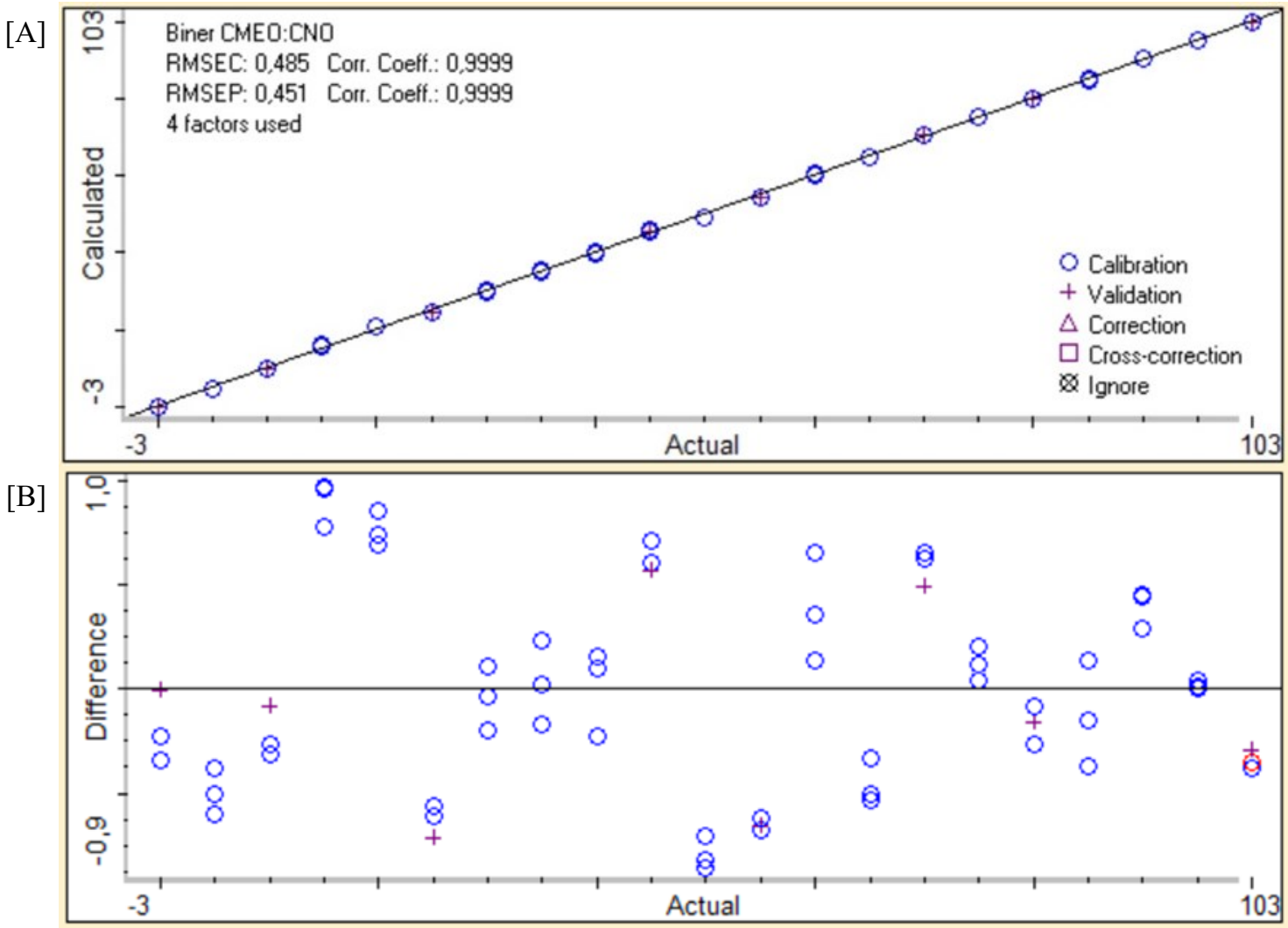

Figure 3. The relationship between actual values (x-axis) of C. mangga Val. Essential Oil (CMEO) in x-axis and the predicted values of CMEO using FTIR spectroscopy [A] along with residual analysis [B].

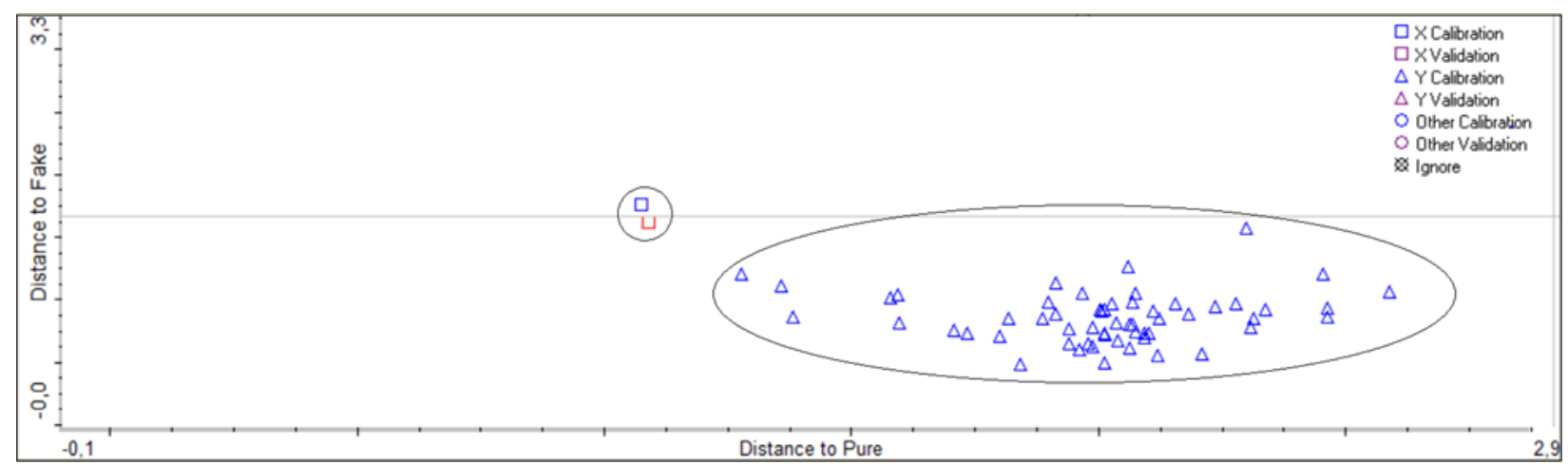

Figure 4. The Cooman's plot obtained during discriminant analysis for discrimination of pure C. mangga Essential Oil (CMEO) and CMEO mixed with Candle Nut Oil (CNO).

(RMSEC) and root mean square error of prediction (RMSEP).

Table 1 compiles the performance results of FTIR spectroscopy using different wavenumbers and spectral treatments coupled with multivariate calibration intended for prediction of EOCM levels adulterated with CNO. PLSR using normal FTIR spectra at wavenumbers of $1614-1068 \mathrm{~cm}^{-1}$ was selected for the quantification of EOCM in CNO due to its capability to provide the highest $\mathrm{R}^{2}$ values (0.9999) either in calibration and prediction with lowest RMSEC value (0.485) and RMSEP value (0.451). The developed models revealed the acceptable accuracy and precision as shown by high values of $\mathrm{R}^{2}$ and low values of RMSEC and RMSEP. Figure 3A exhibited the linear relationship between actual values of EOCM (x-axis) and FTIR predicted values of EOCM (y-axis) using FTIR spectroscopy. From Figure $3 \mathrm{~B}$, the errors occurring during modelling occurred randomly (not systematic error) around zero difference. This indicated that the systematic errors did not exist and the model developed are reliable to predict PSO adulterated with $\mathrm{SeO}$.

Discriminant analysis (DA) is known as the supervised pattern recognition commonly used for discrimination between pure EOCM and EOCM adulterated with CNO (Rohman et al., 2014). The variables used for quantitative analysis were also used for DA. The Mahalanobis distances using these absorbances were then calculated to create Cooman's plot. Figure 4 shows Cooman's plot for classification between EOCM and EOCM adulterated with CNO successfully with accuracy level of $100 \%$, without any misclassification. 


\section{Conclusion}

Fourier transform infrared (FTIR) spectroscopy in combination with chemometrics of multivariate calibration of partial least square regression (PLSR) and chemometrics of discriminant analysis was capable for the quantifying the levels of essential oil of C. mangga Val. (EOCM) adulterated with candlenut oil (CNO) at optimized wavenumbers of 1614-1068 $\mathrm{cm}^{-1}$. The model was valid as indicated by acceptable accuracy and precision as indicated by high $\mathrm{R}^{2}$ and low RMSEC and RMSEP. Discriminant analysis was also success for classification of EOCM and EOCM adulterated with CNO.

\section{Conflict of Interest}

The authors declare no conflict of interest.

\section{Acknowledgement}

The authors thank to Universitas Gadjah Mada (UGM), Yogyakarta Indonesia for financial support during this study through Rekognisi Tugas Akhir 2019 with contract number of 2129/UN1/DITLIT/DIT-LIT/ LT/2019.

\section{References}

Abas, F., Lajis, N.H., Shaari, K., Israf, D.A., Stanslas, J., Yusuf, U.K. and Raof, S.M. (2005). Labdane diterpene glucoside from the rhizomes of Curcuma mangga. Journal of Natural Products, 68, 10901093. https://doi.org/10.1021/np0500171

Alonso-Rebollo, A., Ramos-Gómez, S., Busto, M.D. and Ortega, N. (2017). Development and optimization of an efficient qPCR system for olive authentication in edible oils. Food Chemistry, 232, 827-835. https:// doi.org/10.1016/j.foodchem.2017.04.078

Arslan, F.N., Akina, G., Elmas S.N.K, Yilmaz, I., Janssen, H-G. and Kenar, A. (2019). Rapid detection of authenticity and adulteration of cold pressed black cumin seed oil: A comparative study of ATR-FTIR spectroscopy and synchronous fluorescence with multivariate data analysis. Food Control, 98, 323332. https://doi.org/10.1016/j.foodcont.2018.11.055

Astuti, E., Sunarminingsih, R., Jenie, U.A. and Mubarika, S. (2014). Pengaruh Lokasi Tumbuh, Umur Tanaman dan Variasi Jenis Destilasi Terhadap Komposisi Senyawa Minyak Atsiri Rimpang Curcuma Mangga Produksi Beberapa Sentra di Yogyakarta. Jurnal Manusia dan Lingkungan, 21, 323-330. [In Bahasa Indonesia].

Bajoub, A., Medina-Rodríguez, S., Gómez-Romero, M., Ajal, E., Bagur-González, M.G., Fernández-
Gutiérrez, A. and Carrasco-Pancorbo, A. (2017). Assessing the varietal origin of extra-virgin olive oil using liquid chromatography fingerprints of phenolic compound, data fusion and chemometrics. Food Chemistry, 215, 245-255. https://doi.org/10.1016/ j.foodchem.2016.07.140

Che Man, Y.B., Rohman, A. and Mansor, T.S.T. (2011). Differentiation of lard from other edible oils by means of Fourier transform infrared spectroscopy and chemometrics. Journal of the American Oil Chemists' Society, 88(2), 187 - 192. https:// doi.org/10.1007/s11746-010-1659-x

Dais, P. and Hatzakis, E. (2013). Review Quality assessment and authentication of virgin olive oil by NMR spectroscopy: A critical review. Analytica Chimica Acta, 765, 1-27. https://doi.org/10.1016/ j.aca.2012.12.003

Flores, G., Ruiz Del Castillo, M.L., Herraiz, M. and Blanch, G.P. (2006). Study of the adulteration of olive oil with hazelnut oil by on-line coupled high performance liquid chromatographic and gas chromatographic analysis of filbertone. Food Chemistry, 97(4), 742 - 749. https://doi.org/10.1016/ j.foodchem.2005.06.008

García-Villalba, R., Pacchiarotta, T., Carrasco-Pancorbo, A., Segura-Carretero, A., Fernández-Gutiérrez, A., Deelder, A.M. and Mayboroda O.A. (2011). Gas chromatography-atmospheric pressure chemical ionization-time of flight mass spectrometry for profiling of phenolic compounds in extra virgin olive oil. Journal of Chromatography A, 1218(7), 959971. https://doi.org/10.1016/j.chroma.2010.12.014

Giménez, M.J., Pistón, F., Martín, A.S. and Atienza, G. (2010). Application of real-time PCR on the development of molecular markers and to evaluate critical aspects for olive oil authentication. Food Chemistry, 118(2), 482-487. https://doi.org/10.1016/ j.foodchem.2009.05.012

Indis, N.A. and Kurniawan, F. (2016). Determination of free radical scavenging activity from aqueous extract of Curcuma mangga by DPPH method. Journal of Physics: Conference Series, 710, 1-5. https:// doi.org/10.1088/1742-6596/710/1/012043

Irnawati, Riyanto, S., Martono, S. and Rohman, A. (2020). The employment of FTIR spectroscopy and chemometrics for authentication of pumpkin seed oil from sesame oil. Food Research, 4(1), 42 - 48. https://doi.org/10.26656/fr.2017.4(1).198

Jafari, M., Kadivar, M. and Keramat, J. (2009). Detection of adulteration in Iranian olive oils using instrumental (GC, NMR, DSC) methods. Journal of the American Oil Chemists' Society, 86(2), 103 110. https://doi.org/10.1007/s11746-008-1333-8 
Jena, S., Ray, A., Banerjee, A., Sahoo, A., Nasim, N., Sahoo, S., Kar, B., Patnaik, J., Panda, P.C. and Nayak, S. (2017). Chemical composition and antioxidant activity of essential oil from leaves and rhizomes of Curcuma angustifolia Roxb. Natural Product Research, 31(18), 2188-2191. https:// doi.org/10.1080/14786419.2017.1278600

Jimenez-Carvelo, A.M., Osorio, M.T., Koidis, A., Gonzalez-Casado, A. and Cuadros-Rodríguez, L. (2017). Chemometric classification and quantification of olive oil in blends with any edible vegetable oils using FTIR-ATR and Raman spectroscopy. LWT - Food Science and Technology, 86, 174-184. https://doi.org/10.1016/ j.lwt.2017.07.050

Kaewkroek, K., Wattanapiromsakul, C. and Tewtrakul, S. (2010). Anti-inflammatory mechanism of compounds from Curcuma mangga rhizomes using RAW264.7 macrophage. Natural Product Communications, 5(10), 1547-1550. https:// doi.org/10.1177/1934578X1000501006

Kamazeri, T.S.A.T., Samah, O.A., Taher, M., Susanti, D. and Qaralleh, H. (2012). Antimicrobial activity and essential oils of Curcuma aeruginosa, Curcuma mangga, and Zingiber cassumunar from Malaysia. Asian Pacific Journal of Tropical Medicine, 5(3), 202-209. https://doi.org/10.1016/S1995-7645(12) 60025-X

Lankmayr, E., Mocakb, J., Serdtc, K., Ballab, B., Wenzl, T., Bandoniene, D., Gfrerer, M. and Wagner, S. (2004). Chemometrical classification of pumpkin seed oils using UV-Vis, NIR and FTIR spectra. Journal of Biochemical and Biophysical Methods, 61 (1-2), 95-106. https://doi.org/10.1016/ j.jbbm.2004.04.007

Liu, Y. and Nair, M.G. (2012). Curcuma longa and Curcuma mangga leaves exhibit functional food property. Food Chemistry, 135(2), 634-640. https:// doi.org/10.1016/j.foodchem.2012.04.129

Manaf, M.A., Man, Y.B.C., Hamid, N.S.A., Ismail, A. and Abidin, S.Z. (2007). Analysis of adulteration of virgin coconut oil by palm kernel olein using Fourier transform infrared spectroscopy. Journal of Food Lipids, 14(2), 111-121. https:// doi.org/10.1111/j.1745-4522.2007.00066.x

Nurrulhidayah, A.F., Che Man, Y.B. and Rohman, A. (2014). FTIR Spectroscopy Combined with Chemometric for Analysis of Sesame Oil Adulterated with Corn Oil. International Journal of Food Properties, 17(6), 1275-1282. https:// doi.org/10.1080/10942912.2012.689409

Nurwahidah, A.T., Rumiyati, Riyanto, S., Nurrulhidayah A.F., Betania, K. and Rohman, A. (2019). Fourier
Transform Infrared Spectroscopy (FTIR) coupled with multivariate calibration and discriminant analysis for authentication of extra virgin olive oil from rambutan seed fat. Food Research, 3(6), 727733. https://doi.org/10.26656/fr.2017.3(6).182

Padalia, R.C., Verma, R.S., Sundaresan, V., Chauhan, A., Chanotiya, C.S. and Yadav, A. (2013) Volatile terpenoid compositions of leaf and rhizome of Curcumaamada Roxb. from Northern India. Journal of Essential Oil Research, 25(1), 17-22. https:// doi.org/10.1080/10412905.2012.747271

Putri, A.R., Rohman, A. and Riyanto, S. (2019). Authentication of Patin (Pangasius micronemus) fish oil adulterated with palm oil using FTIR spectroscopy combined with chemometrics. International Journal of Applied Pharmaceutics, 11 (3), 195-199. https://doi.org/10.22159/ ijap.2019v11i3.30947

Rahayu, W.S., Rohman, A., Martono, S. and Sudjadi. (2018). Application of FTIR Spectroscopy and Chemometrics for Halal Authentication of Beef Meatball Adulterated with Dog Meat. Indonesian Journal of Chemistry, 18(2), 376-381. https:// doi.org/10.22146/ijc.27159

Rohman, A. and Putri, A.R. (2019). The application of instrumental analysis coupled with chemometrics for halal authentication: a review. Indonesian Journal of Chemistry, 19(1), 262-272. https://doi.org/10.22146/ ijc. 28721

Sriroda, S. and Tewtrakul, S. (2019). Anti-inflammatory and wound healing effects of cream containing Curcuma mangga extract. Journal of Ethnopharmacology, 238, 111828. https:// doi.org/10.1016/j.jep.2019.111828

Tamta, A., Prakash, O., Punetha, H. and Pant, A.K. (2016). Chemical composition and in vitro antioxidant potential of essential oil and rhizome extracts of Curcuma amada Roxb. Cogent Chemistry, 2, $1168067 . \quad \mathrm{https} / / /$ doi.org/10.1080/23312009.2016.1168067

Van Wetten, I.A., Van Herwaarden, A.W., BoerrigterEenling, S.R. and Van Ruth, S.M. (2015). Detection of sunflower oil in extra virgin olive oil by fast differential scanning calorimetry. Thermochimica Acta , 603, 237-243. https://doi.org/10.1016/ j.tca.2014.11.030

Wong, K.C., Chong, T.C. and Chee, S.G. (1999) Essential Oil of Curcuma mangga Val. and van Zijp Rhizomes. Journal of Essential Oil Research, 11(3), 349-351. https:// doi.org/10.1080/10412905.1999.9701151 